\title{
Effects of chemical cues on settlement behavior of blue crab Callinectes sapidus postlarvae
}

\author{
James M. Welch*, Dan Rittschof, Traci M. Bullock, Richard B. Forward Jr \\ Duke University, Department of Zoology, Duke University Marine Laboratory, 135 Duke Marine Lab Road, Beaufort, \\ North Carolina 28516, USA
}

\begin{abstract}
Settlement of blue crab Callinectes sapidus Rathbun postlarvae (megalopae) was examined in the field in the presence and absence of chemical cues from settlement habitats and potential megalopal predators. Megalopae in premolt preferentially settled on collectors containing seagrasses Zostera marina and Halodule wrightii, but not on collectors with salt marsh cordgrass Spartina alterniflora. Settlement of megalopae was reduced by up to $40 \%$ in the presence of predators from several different habitats, including crabs UCa pugilator, U. pugnax and Panopeus herbstii, and grass shrimp Palaemonetes pugio. Laboratory predation assays showed that each of these potential predators ate $C$. sapidus megalopae if they encountered them. Megalopae avolded odors of $U$. pugilator in chemotaxis assays, and showed no reaction to odors from Z. marina and S. alterniflora. Settlement of megalopae was unaffected by the presence of adult $C$. sapidus or brown shrimp Penaeus aztecus, neither of which consumed megalopae in laboratory predation assays. Megalopae showed no reaction to fouled shells of oyster Crassostrea virginica, but avolded live C. virgınica. Thus, settling blue crab megalopae can distinguish among settlement sites using chemical cues, and their discrimination ability increases in the premolt stage.
\end{abstract}

KEY WORDS: Chemical cues Settlement site selection - Callinectes sapidus - Megalopae - Postlarvae. Eelgrass Predators - Chemotaxis B Blue crab

\section{INTRODUCTION}

Most benthic invertebrates have a planktonic larval stage. A critical step in the life cycle of these animals is the transition from a planktonic to a benthic existence: settlement in a favorable benthic site increases the likelihood of survival, while settlement in an unfavorable site could lead to high post-settlement mortality due to predation or physiological stress. Both positive and negative mechanisms for selection by chemical cues are possible (reviewed by Pawlik 1992, Rittschof et al. 1997).

Among invertebrates, examples of positive chemical cues for settlement include gregarious settlement of larvae using chemical cues released by adults (e.g Burke 1984, 1986, Zimmer-Faust \& Tamburri 1994). Gregarious settlement by the postlarval stage (megalopa) of fiddler crabs Uca pugilator (Christy 1989.

·E-mail: jmw5@mail.duke.edu
O'Connor 1991) and porcelain crabs Petrolisthes spp. (Jensen 1989) is also chemically mediated. Metamorphosis of blue crab Callinectes sapidus megalopae is accelerated by cues in estuarine water (Forward et al. 1994, 1996, Wolcott \& De Vries 1994). Evidence for negative cues for settlement among larvae of large mobile crustaceans is restricted to the settlement stage of Homarus americanus, which swims down-current in response to fish odors in laboratory experiments (Boudreau et al 1993).

Blue crab Callinectes sapidus megalopae are likely candidates for study of both positive and negative chemical cues for settlement. Larvae develop offshore (Provenzano et al. 1983), are transported landward as megalopae by wind-driven surface currents (Goodrich et al. 1989), and move up-estuary using selective tidal stream transport (e.g. Little \& Epifanio 1991, De Vries et al 1994, Olmi 1994). Once in estuaries, megalopae and early-stage crabs are found primarily in seagrass beds (Orth \& van Montfrans 1987). However, it is 
unknown if this distribution is determined by selective settlement or by post-settlement processes such as predation or migration. Blue crab megalopae are strong swimmers, capable of swimming against a sustained $5 \mathrm{~cm} \mathrm{~s}^{-1}$ current (Luckenbach \& Orth 1992). Thus, as in the case of lobster (Boudreau et al. 1993), they have the potential to move toward or away from specific areas.

This study examined the effects of chemical cues on settlement behavior of blue crab megalopae. The test hypothesis was that blue crab megalopae actively select or reject potential settlement sites based on the presence of favorable or adverse chemical cues. A series of experiments examined settlement on field collectors with and without different chemical cues. Laboratory experiments determined chemotactic responses to settlement cues and whether observed relationships in the field could be explained by potential predation on megalopae. Settlement on field collectors varied with chemical cues and with molt stage of the megalopae. Settling megalopae were attracted by chemical odors from seagrass beds, avoided collectors with potential predators, and showed no reaction to odors from non-predators.

\section{METHODS}

Field settlement experiments. Field settlement experiments were conducted using collectors modified from the design of Metcalf et al. (1995). The collector consists of a removable sleeve of hog's hair filter material surrounding an inner cylinder made of $13 \mathrm{~mm}$ mesh size Vexar® diamond mesh (InterNet, Inc. stock no. XB-8210) (Fig. 1). Support is provided by wood discs at the top and bottom of the cylinder. Odor sources (e.g. predators or seagrass) were placed in the inner cylinder inside bags made of fiberglass window screening material. The odor sources were exposed to water flow, but physically separated from the actual settlement site, the hog's hair Megalopae were presented with identical physical environments on treatment and control collectors; the only difference was the presence or absence of the chemical cue.

Experiments were conducted in the Newport River Estuary, near Beaufort, North Carolina, USA, beneath a platform suspended from a bridge about $1 \mathrm{~km}$ inside the estuary mouth. For each experiment, 4 empty collectors (control) and 4 collectors with odor sources inside (treatment) were suspended from the platform such that they were just below the surface at spring low tide. Thus, the depth of the collectors varied from the surface at low tide to approximately $1 \mathrm{~m}$ below the surface at high tide. Positions for suspension from the platform of treatment and control collectors were randomly determined, and were re-randomized every day. Odor sources were replaced every other day. Collectors were harvested daily according to a standard protocol (see Metcalf et al. 1995 for details). Briefly, the hog's hair sleeves were removed and megalopae were rinsed off using a freshwater hose; the rinsewater was collected in buckets and sieved to remove megalopae Megalopae were preserved in $80 \%$ ethanol, or placed in seawater for determination of molt stage. Megalopae were taxonomically identified and counted in the laboratory using a dissecting microscope. When molt staging was performed, megalopae were sorted into premolt and intermolt categories by examining cuticle withdrawal from the rostral spine and the uropods (Aiken 1973, Lipcius et al. 1990). For molt stage determination, first instar crabs were considered 'premolt' as it was assumed that they settled the previous night as megalopae and molted into crabs while on the collectors. This is supported by the fact that megalopal exuviae were often found on collectors containing first crabs, and that plankton collection at night rarely captures first crabs (Forward unpubl. obs.). First instar crabs comprised only 0.5 to $10 \%$ of total settlement. Geneldily, 100 settiers on a coilector were molt staged and the remaining megalopae were counted.

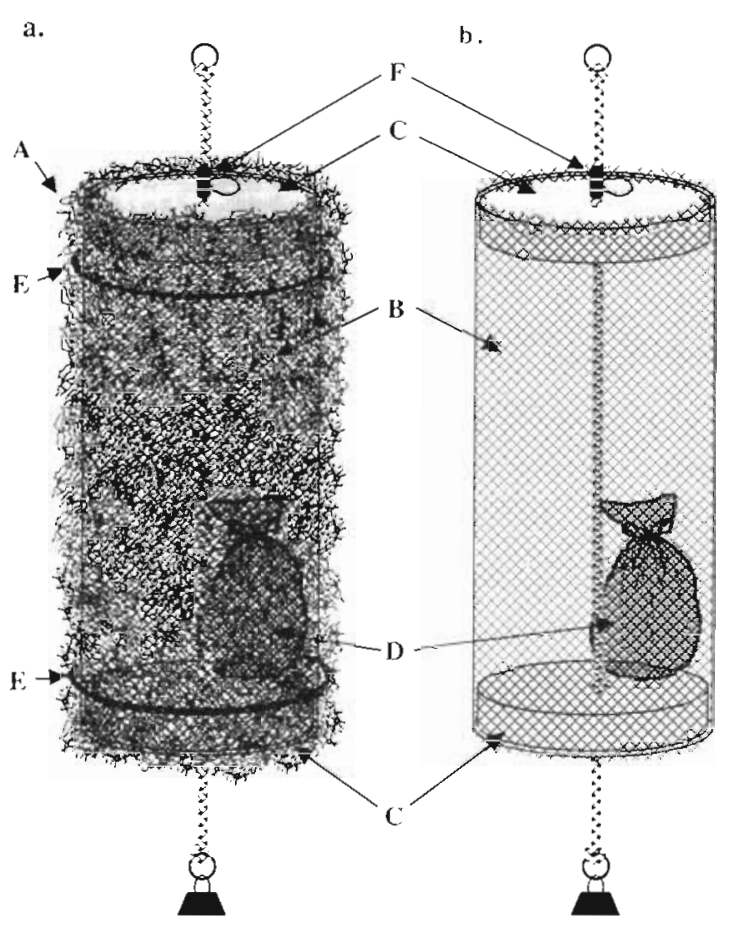

Fig. 1 Collectors used in settlement experiments: (a) assembled collector and (b) collector with hog's halr filter removed to show details. Settlement substrate ( $A_{\text {; }}$ hog's hair filter material) supported by Vexar( mesh (B) and wood discs (C). The top wood disc is secured by a binder clip (F) which can be removed to allow access to the inside of the collector. Mesh bag (D) containing an odor source and (E) rubber bands used to secure hog's hair to the collector 
Experiments lasted $6 \mathrm{~d}$, because preliminary results showed that this was sufficient time to demonstrate a response to settlement cues. An exception is the experiment using Palaemonetes pugio, which was extended to $8 d$ since settlement was extremely low for the first $3 \mathrm{~d}$ of the experiment. The experiments were performed in the fall of 1995 and 1996, from August through October, which is usually the period of highest settlement of Callinectes sapidus megalopae in the test estuary (Forward unpubl. data). Experiments were divided according to different potential settlement sites and their associated odors. Site types examined were seagrass beds, sandy substrate, salt marshes, and oyster beds. Seagrass beds were represented by seagrasses Zostera marina and Halodule wrightii and by adult blue crabs; sandy substrates were represented by sand fiddler crabs Uca pugilator and brown shrimp Penaeus aztecus. From salt marshes, cordgrass Spartina alterniflora was tested along with potential predators mud fiddler crabs Uca pugnax and grass shrimp $P$. pugio. Odors from oyster beds which were tested were fouled oyster Crassostrea virginica shells, live oysters, and mud crabs Panopeus herbstii. Weights of odor sources in each collector were as follows: for grasses, approximately $200 \mathrm{~g}$ cut into $15 \mathrm{~cm}$ lengths, which was the maximum amount that would fit into the bags inside the collectors; for potential predators, approximately $50 \mathrm{~g}$ of live weight, excluding $C$. sapidus and $P$. herbstii. One adult $C$. sapidus $(\sim 125 \mathrm{~g})$ was used per treatment collector because only one would fit, and only $6 P$. herbstii (total weight $\sim 25 \mathrm{~g}$ ) were used due to concerns of cannibalism among test animals. All test animals were of average size for their species. For oyster experiments, either 5 individual valves (length $\sim 15 \mathrm{~cm}$ ) were used in fouled shell experiments or 3 live oysters of the same length were used.

Differences in settlement were examined using a block design ANOVA, with day as the block and treatment versus control as the factor (SYSTAT 1995). Proportions of settlers in premolt were compared between treatments using a similar ANOVA. Proportions were arcsine transformed before analysis to ensure normality of residuals. If mean settlement for a day was less than 4 megalopae per collector, that day was excluded from molt stage analysis to prevent undue influence of a few individuals on proportions.

Predation experiments. Feeding assays were conducted in the laboratory to determine whether observed patterns in settlement could be explained by potential predation pressure on blue crab megalopae. Megalopae for the predation assays were collected during flood tides at night using plankton nets $10.67 \mathrm{~m}$ diameter, $505 \mu \mathrm{m}$ mesh) suspended from the same platform used in the collector experiments. Megalopae were held in $19 \mathrm{~cm}$ diameter finger bowls containing offshore seawater, at $23^{\circ} \mathrm{C}$, until experimentation. Offshore water was collected $15 \mathrm{~km}$ seaward of the Newport River Estuary Inlet and had a salinity of 35 psu as measured with a refractometer (American Optical). This water was beyond the estuarine plume and from an area where megalopae were collected previously in the neuston (Forward \& Rittschof 1994). Water was changed daily, and megalopae were fed an excess of newly hatched Artemia franciscana nauplii. Megalopae were maintained in offshore water to reduce exposure to predator chemical cues and to estuarine chemical cues that accelerate metamorphosis (Forward et al. 1996).

Assays for predation by the crabs UCa pugilator, $U$. pugnax, and Panopeus herbstii and the shrimp Palaemonetes pugio were conducted in $19 \mathrm{~cm}$ finger bowls, with a $1 \mathrm{~cm}$ deep layer of sand in the bowl. Sand was collected from a beach in the test estuary, heated in a muffle furnace to $500^{\circ} \mathrm{C}$ for $24 \mathrm{~h}$, and sieved to remove particles $>500 \mu \mathrm{m}$. For fiddler crabs, $50 \mathrm{ml}$ of filtered estuarine seawater (salinity 32 to 35 psu) was placed in the bowl (enough to saturate the sand); for other predators $250 \mathrm{ml}$ of estuarine seawater was used. There were 4 replicate treatment bowls containing 15 megalopae and 2 predators and 4 replicate control bowls containing megalopae, water and sand, but no predators. Predators were of the same size as those used in settlement experiments, and were starved for $1 \mathrm{~d}$ prior to experimentation. Bowls were held in an environmental chamber (Sherer model CEL-4) at $23^{\circ} \mathrm{C}$ and $\mathrm{a} 14 \mathrm{~h}$ light: $10 \mathrm{~h}$ dark photoperiod (light intensity = $6.2 \times 10^{15}$ photons $\mathrm{cm}^{-2} \mathrm{~s}^{-1}$ ) for the $24 \mathrm{~h}$ duration of the assays, which began midway through the light phase At the conclusion of the assay, megalopae were collected from all bowls using a $500 \mu \mathrm{m}$ sieve. Numbers of megalopae remaining in treatment and control bowls were compared using Student's $t$-test.

Assays for predation by adult blue crabs and shrimp Penaeus aztecus were conducted in small glass aquaria $(25 \times 18 \times 18 \mathrm{~cm})$ because of the larger size of these species. Each aquarium held 6 l of filtered estuarine seawater and had a $2 \mathrm{~cm}$ deep layer of sand. Fifteen megalopae were placed in the aquaria, along with 1 predator Aquaria were held under the same conditions as finger bowls, and numbers of megalopae remaining after $24 \mathrm{~h}$ were again compared using Student's $t$-test.

Chemotaxis experiments. A series of experiments was conducted in the laboratory to examine the movement of blue crab megalopae in response to chemical odors (chemotaxis). Experiments were conducted in total darkness in a rectangular $12.5 \times 2.5 \times 2.5 \mathrm{~cm}$ chamber. The chamber was divided into 5 equal sections separated by removable partitions. For each experimental run, $50 \mathrm{ml}$ of offshore seawater was placed 
into the chamber and the partitions were inserted. A cotton ball (diameter $-1.5 \mathrm{~cm}$ ) soaked with water containing an odor (see below) was placed at one randomly selected end of the chamber, and 15 megalopae were added to the center section with the partitions in place. Megalopae were allowed to equilibrate for $1 \mathrm{~min}$ before the partitions were removed. The megalopae were then allowed to swim about the chamber for 2 min, after which the partitions were reinserted and the horizontal position of each megalopa was recorded. Positions were scored as the compartment with the cotton ball being 1, the opposite end being 5 . Preliminary experiments showed that during the 2 min, megalopae distributed themselves randomly within the chamber in the absence of any stimulus, either with or without a cotton ball.

The odors tested were Spartina alterniflora, Zostera marina, Uca pugilator, and estuarine water, in addition to controls with no cotton ball and with a cotton ball soaked in offshore seawater. Offshore water was considered to be devoid of cues. Odors were prepared by allowing the source to incubate in offshore seawater

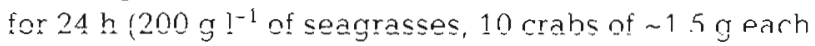

total weight in $200 \mathrm{ml}$ seawater). Estuarine water (salinity 32 to $35 \mathrm{psu}$ ) was collected about $1 \mathrm{~km}$ inside the Newport River Estuary falling tide immediately before experimentation; offshore water was collected as for the predation experiments. Since field results were similar for all predators that ate megalopae, fiddler crabs were used as a representative predator.

Final positions of the megalopae were compared using a nested ANOVA, with finishing positions nested within experimental runs. Treatments were compared to the control (cotton soaked in offshore seawater) by Dunnett's multiple range test (Zar 1984).

\section{RESULTS}

\section{Field settlement assays}

Settlement was highly variable from day to day in all experiments; the day factor was always significant (ANOVA, all $p \ll 0.05$ ). In molt stage analysis, day was significant $(p<0.05) 3$ out of 8 times (experiments with Spartina alterniflora: Uca pugnax. and Penaeus aztecus).

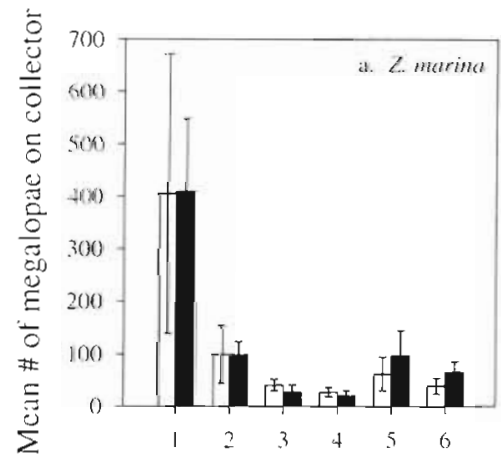

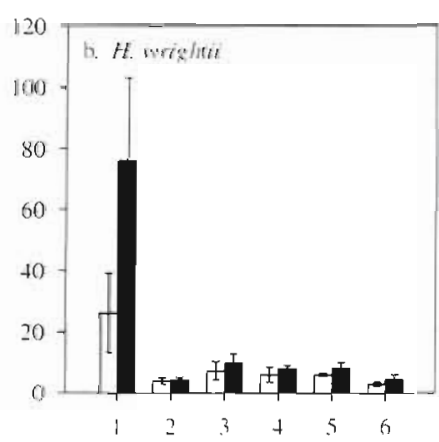

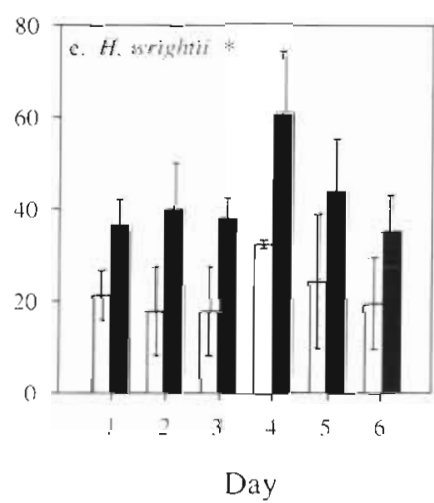

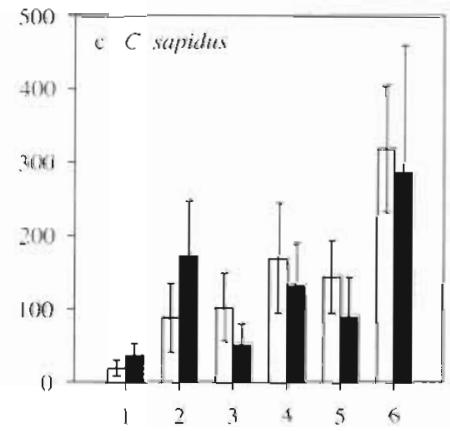

Day

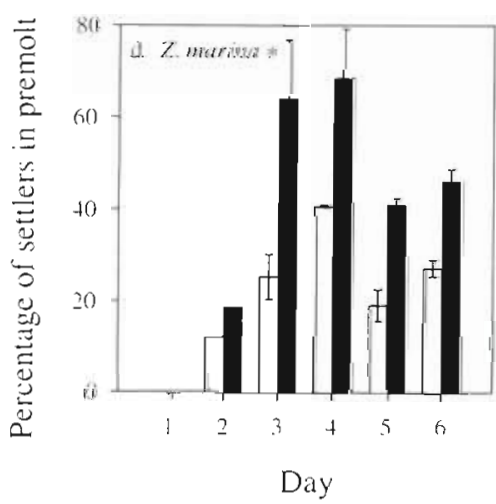

Fig. 2. Callinectes sapidus. Settlement with odors representatıve of seagrass beds. Mean ( \pm SE) numbers of megalopae settling on control collectors (open bars) and collectors with an odor source (filled bars) in experiments with (a) Zostera marina, (b) Halodule wrightii, and (c) adult $C$. sapidus are shown for each of the 6 sampling days. Percentages of settling megalopae that were in premolt on the collectors containing (d) $Z$. marina and (e) $H$. wrightii are also shown. The experiment with adult $C$. sapidus was performed before molt staging was begun. $n=4$ for each treatment, except that the Day 2 molt stage data for the $Z$. marina experiment as 1 collector per treatment. "Significant difference between control and treatment collectors $($ ANOVA, $p<0.05)$ 
Settlement with odors representative of seagrass beds

In settlement experiments, survival of test animals confined in the collectors was always greater than $90 \%$. This indicates that there was sufficient water flow through the collectors to supply the test animals with oxygen, remove wastes and transfer chemical cues from the odor sources to the surrounding water.

In total, more Callinectes sapidus megalopae settled on collectors containing Zostera marina than on empty collectors (Fig. 2a). However, the difference was not statistically significant $\left(F_{1,34}=0.020, \mathrm{p}>\right.$ 0.05). On the second day, the settlers on 1 collector of each type were molt staged, and since a difference was found, ali settlers on succeeding days were molt staged. Significantly more premolt megalopae settled on collectors containing $Z$. marina than on control collectors $\left(F_{1,26}=13.129, \mathrm{p}<0.01 ;\right.$ Fig. 2d). More megalopae also settled on collectors containing Halodule wrightii than on empty collectors (Fig. 2b). As in the case of $Z$. marina, however, the difference was not statistically significant $\left(F_{1,76}=3.721, \mathrm{p}>0.05\right)$. Again, molt stages were examined, and significantly more premolt megalopae settled on collectors containing $H$. wrightii than on empty collectors $\left(F_{1,30}=\right.$ 9.154, $\mathrm{p}<0.01$; Fig 2e)

There was no statistically significant difference between settlement onto collectors with and without adult Callinectes sapidus $\left(F_{1,36}=0.081, \mathrm{p}>0.05\right.$ Fig. 2c). On 2 days, more megalopae settled on collectors with $C$. sapidus, but on 4 days, more megalopae settled on empty collectors (Fig. 2c). Molt stages of settlers were not determined in this experiment; it was performed before molt staging was begun.

\section{Settlement with odors representative of sandy substrates}

Significantly fewer megalopae settled on collectors containing fiddler crabs Uca pugilator than on empty collectors $\left(F_{1,34}=4.629, p<0.05\right.$; Fig. 3a). On no day did more megalopae settle on treatment collectors than on empty collectors. Molt stage was not determined in this experiment because it was performed before molt staging was begun.

There was no significant difference in settlement on collectors with and without brown shrimp Penaeus aztecus $\left(F_{1,38}=0.045, \mathrm{p}>0.05\right.$; Fig. $\left.3 \mathrm{~b}\right)$. There was also no effect of $P$. aztecus odors on molt stages of settlers $\left(F_{1,27}=3.585, \mathrm{p}>0.05 ;\right.$ Fig. $\left.3 \mathrm{c}\right)$. Days 5 and 6 were excluded from molt stage analysis due to low settlement.

\section{Settlement with odors representative of salt marshes}

No significant difference was found in settlement to collectors with and without salt marsh cordgrass Spartina alterniflora $\left(F_{1,41}=0.690, \mathrm{p}>0.05\right.$; Fig $\left.4 \mathrm{a}\right)$, nor was there a significant difference in molt stages of the settlers $\left(F_{1,41}=0.001 ; p>0.05 ;\right.$ Fig. $\left.4 d\right)$. As for predators associated with salt marshes, significantly
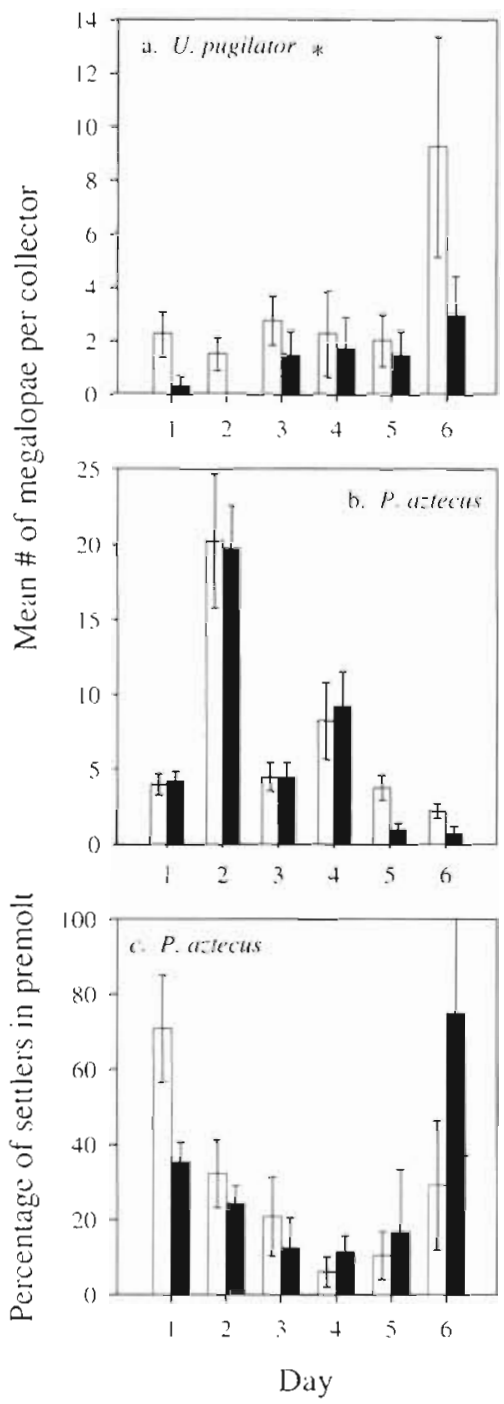

Fig. 3. Callinectes sapidus. Settlement with odors from potential predators occurnng in unvegetated areas. Mean $( \pm S E$ ) numbers of megalopae settling on control collectors (open bars) and collectors with an odor source (filled bars) in experiments with (a) Uca pugilator and (b) Penaeus aztecus for each of the 6 sampling days. (c) Percentage of settlers in premolt on collectors in experiment with $P$ aztecus. The experiment with $U$. pugilator was performed before molt staging was begun. $\mathrm{n}=4$ for each treatment. *Significant difference between control and treatment collectors (ANOVA, $p<0.05$ ) 

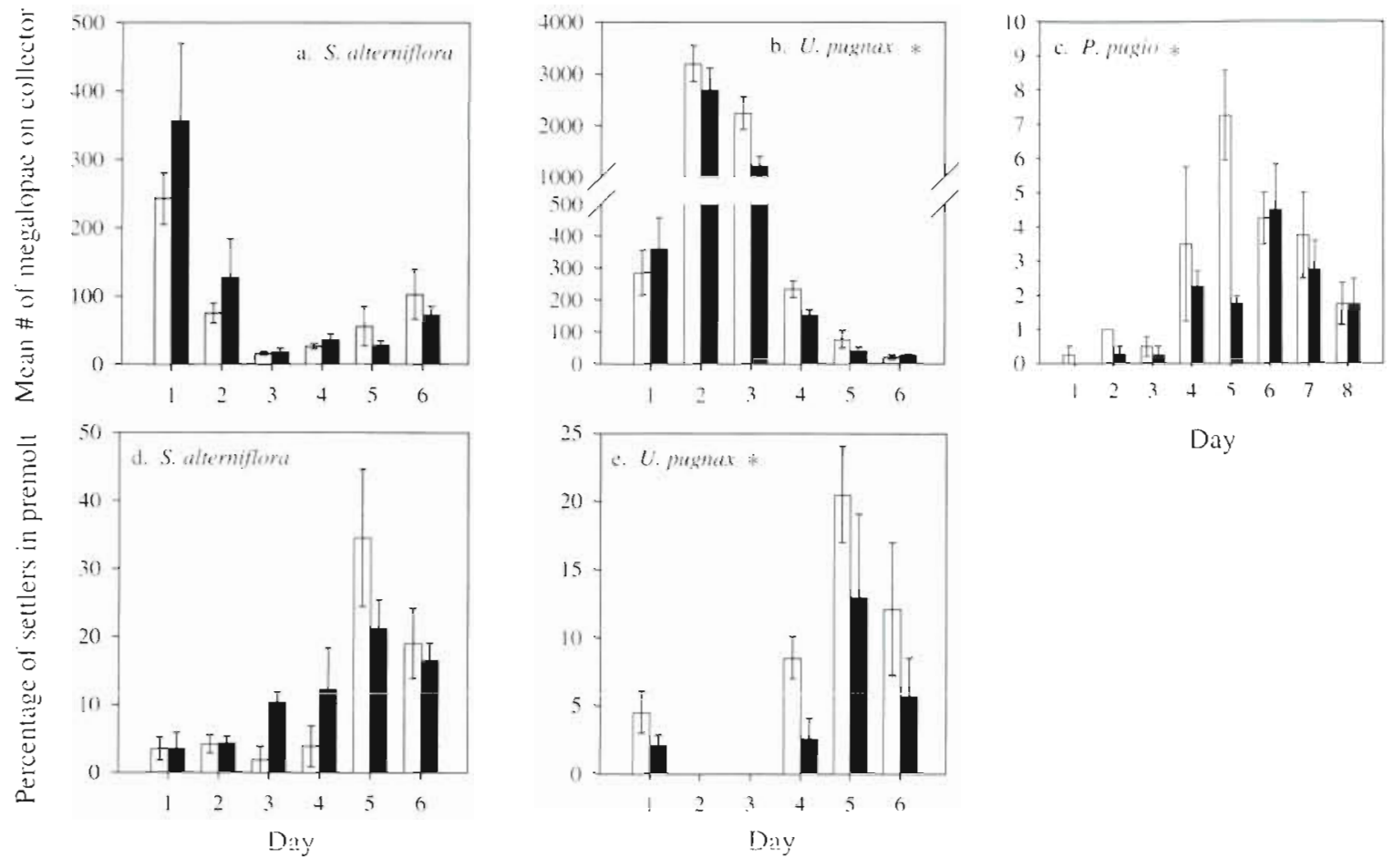

Day

Fig. 4. Callinectes sapidus. Settlement with odors representative of salt marshes. Mean ( \pm SE) numbers of megalopae settling on control collectors (open bars) and collectors with an odor source (filled bars) in experiments with (a) Spartina alterniflora, (b) Uca pugnax, and (c) Palaemonetes pugio for each of the sampling days. Percentages of settlers in premolt in experiments with (d) $S$. alterniflora and (e) $U$. pugnax are also shown. Low settlement prevented molt stage analysis for the $P$. pugio experiment. $n=4$ for each treatment. *Significant difference between control and treatment collectors (ANOVA, $p<0.05$ )

fewer blue crab megalopae settled on collectors containing fiddler crabs $U$ ca pugnax than on empty collectors $\left(F_{1,41}=4.710, \mathrm{p}<0.05 ;\right.$ Fig. $\left.4 \mathrm{~b}\right)$. Megalopae in premolt showed even stronger selectivity $\left(F_{1,27}=6.167\right.$, $\mathrm{p}<0.05$; Fig. 4e); proportionally fewer premolt megalopae settled on the collectors containing $U$. pugnax. During the large settlement pulse (Days 2 and 3) megalopae were not formally molt staged due to the time necessary to process megalopae on these days. However, observations during counting indicated that virtually all of the megalopae were in intermolt.

Settling blue crab megalopae also avoided grass shrimp Palaemonetes pugio $\left(F_{1,55}=5.180, p<0.05\right.$; Fig. 4c). Because settlement during this experiment was generally low, the experiment was extended by 2 d. Also due to the low settlement numbers, molt stages of settlers could not be compared reliably.

Settlement with odors representative of oyster beds

No significant difference was found in settlement to collectors with and without fouled oyster shells $\left(F_{1.29}=\right.$ 1.85. $\mathrm{p}>0.05$; Fig. 5a). There also was no effect on the molt stages of settlers $\left(F_{1,29}=1.03, p>0.05\right.$; Fig. $5 d$ ).
Live oysters Crassostrea virginica were a negative cue for settlement by blue crab megalopae. Megalopae avoided collectors containing oysters $\left(F_{1,37}=6.854\right.$, $\mathrm{p}<0.05$; Fig. 5b). Premolt megalopae showed higher selectivity; the proportion of settlers in premolt was higher on collectors without oysters $\left(F_{1,37}=16.186\right.$, $\mathrm{p} \ll 0.001$; Fig. 5e).

A predator associated with oyster beds, the Atlantic mud crab Panopeus herbstil, was also tested. Blue crab megalopae avoided collectors containing mud crabs $\left(F_{1.41}=5.701, p<0.05 ;\right.$ Fig. $\left.5 c\right)$. Premolt megalopae again showed more selectivity, settling more frequently on the control than the treatment collectors $\left(F_{1,41}=8.187, \mathrm{p}<0.01 ;\right.$ Fig. $\left.5 f\right)$.

\section{Predation assays}

Laboratory assays tested predators' abilities to consume megalopae. In all assays, all megalopae were recovered in every control vessel (Fig 6). Adult blue crabs Callinectes sapidus did not eat megalopae (Fig. 6). Among predators from sandy substrates, fiddler crabs Uca pugilator ate blue crab megalopae, but brown shrimp Penaeus aztecus did not (Fig 6). Of the 

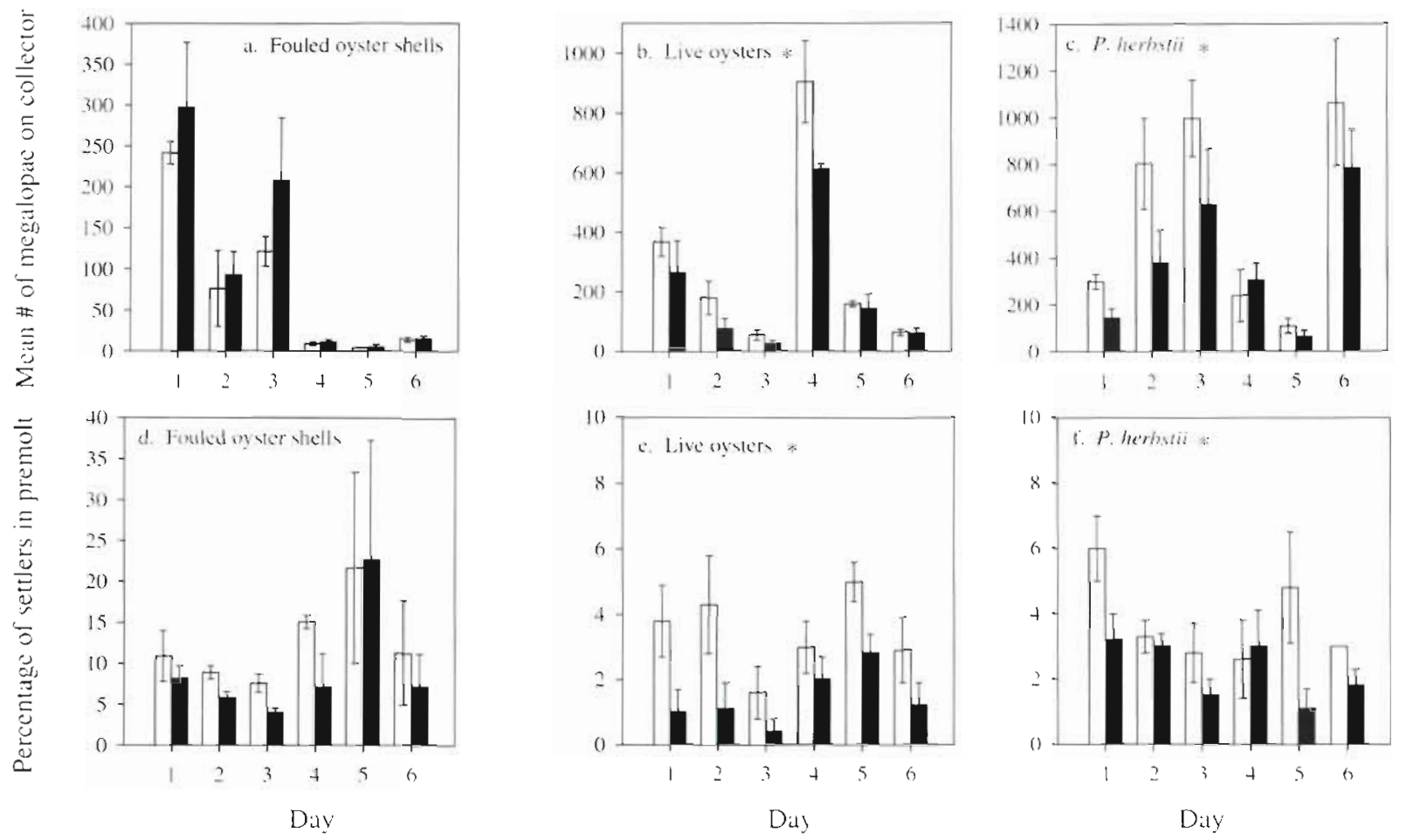

Fig. 5. Callnectes sapidus. Settlement with odors representative of oyster reefs. Mean ( \pm SE) numbers of megalopae settling on control collectors (open bars) and collectors with an odor source (filled bars) in experiments with (a) fouled oyster Crassostrea virginica shells, (b) live oysters C. virginica, and (c) Panopeus herbstij for each of the 6 sampling days. Proportion of settlers in premolt on collectors in experiments with (d) fouled oyster shells, (e) C. virginica, and (f) $P$. herbstii are also shown. $n=4$ for each treatment. "Significant difference between control and treatment collectors for all days (ANOVA, $p<0.05$ )

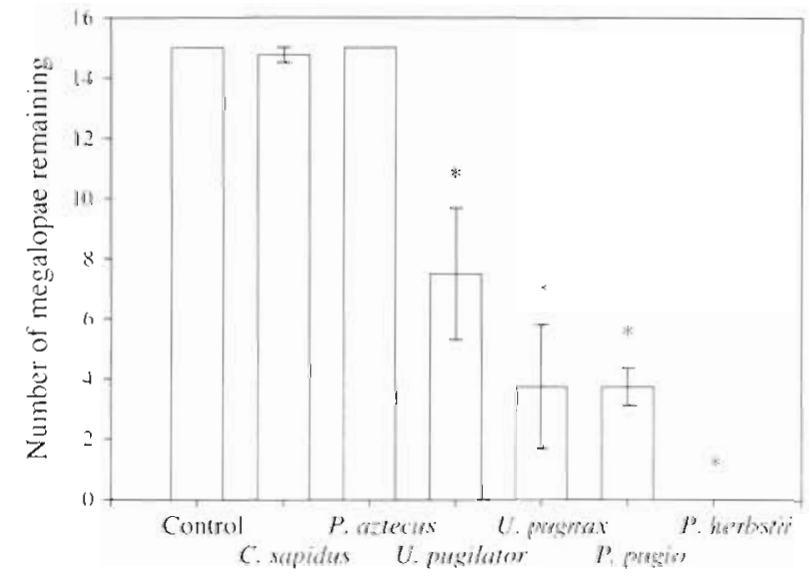

Predator

Flg. 6. Callinectes sapidus. Results of predation assays. Mean $( \pm \mathrm{SE})$ numbers of megalopae remaining after $24 \mathrm{~h}$ exposure to predators (C. sapidus, Penaeus aztecus, Uca pugilator, U. pugnax, Palaemonetes pugio, and Panopeus herbstii). Although controls were run for each experiment, they were all identical and are therefore shown in a single bar *Significant difference (Student's $t$-test, $p<0.05$ ) between numbers of megalopae remaining in treatment and control vessels. $\mathrm{n}=$ 4 for each treatment
2 marsh predators tested, the mud fiddler crab $U_{C a}$ pugnax and the grass shrimp Palaemonetes pugio, both ate megalopae (Fig. 6). Mud crabs Panopeus herbstii, which occur in oyster beds, ate all blue crab megalopae presented to them (Fig. 6).

\section{Chemotaxis experiments}

In both an empty control chamber and a control chamber with a cotton ball soaked in offshore seawater, megalopae distributed themselves randomly within the chamber $\left(\chi_{4}^{2}=1.296, \chi_{4}^{2}=0.056\right.$ respectively, $p>0.05$ ) Because of this, it was assumed that the finishing positions of individual megalopae were independent of each other, as required by the ANOVA.

Megalopae showed no significant reaction (either attraction or avoidance) to the presence of odors derived from Spartina alterniflora, Zostera marina, or estuarine seawater (Dunnett's multiple range test, $p>0.05$; Fig. 7). However, megalopae moved away from a cotton ball soaked with odors from adult $U_{C a}$ pugilator $(\mathrm{p}<0.01)$. 


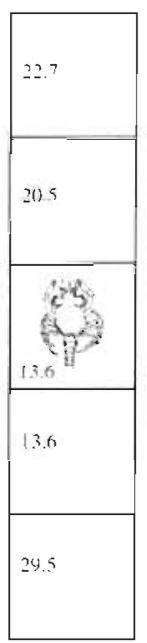

Control

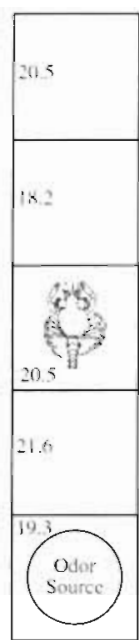

Offshore seawater

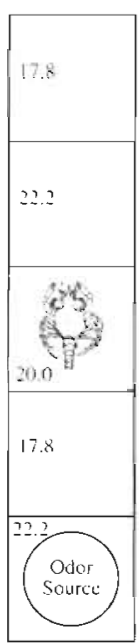

\section{Zostera} marina

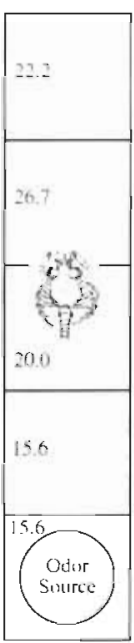

Spartina altemiflora

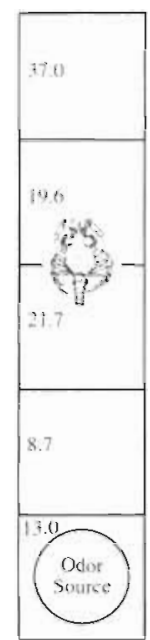

Estuarine seawater

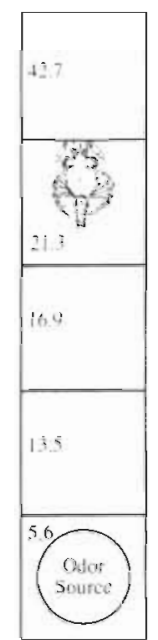

Uca pugilarus
Fig. 7 Callinectes sapidus. Results of laboratory chemotaxis assays. Megalopae figures represent mean finishing positions of megalopae in chambers (see 'Methods: chemotaxis experiments'). Circle represents position of cotton ball soaked with odor source in experiments. Numbers in compartments represent mean percentage of megalopae in that compartment for that odor source. Odor sources are listed below each chamber. $\mathrm{n}=3$ for each treatment, except for the offshore seawater control and Uca pugilator assays, where $n=6$ runs

\section{DISCUSSION}

The present study found that blue crab megalopao detected and reacted to chemical odors, and they showed all 3 of the possible responses to odor sources presented to them: they were attracted to odors from seagrass beds (Fig. 2), repelled by odors associated with potential predators (e.g. Uca pugnax and Palaemonetes pugio, Fig, 4), and showed no reaction to large crustaceans that did not eat megalopae in laboratory assays (e.g. Penaeus aztecus, Fig. 3). The chemotaxis experiments confirmed the ability of blue crab megalopae to detect and respond directionally to chemical cues.

One odor which would be likely to attract megalopae is that of seagrass. Recently settled megalopae are more commonly found in seagrass beds than on adjacent unvegetated bottom strata (Orth \& van Montfrans 1987). However, the mechanisms that establish and maintain this distribution are unknown. Likely mechanisms include selective settlement (i.e. attraction) or post-settlement processes such as migration or predation. Our results support the hypothesis of selective settlement. Megalopae in premolt selected for collectors containing either of the dominant seagrasses in the test estuary (Zostera marina and Halodule wrightii). This could be explained either by positive selection of a settlement site by these premolt megalopae or by induction of the progression from intermolt to premolt by the presence of the seagrass (Forward et al. 1994, 1996). Induction is unlikely, because the technique used minimized the time megalopae were exposed to the cues. Collectors were always harvested in the morning, and megalopae were assumed to have settled during the rising tide the night before, since megalopae are rarely in the water column at any other time (e.g. De Vries et al. 1994, Forward \& Rittschof 1904, Olmi 1994). Since metamoriphosis is accelerded after several days of exposure to seagrass odors (Forward et al. 1994, 1996), the initiation of progression toward premolt occurs on time scales of days, not a few hours. Thus, it is unlikely that the increase in the proportion of settlers in premolt is due to post-settlement induction by the seagrass odors. Rather, it is evidence of selection for seagrass sites by settling premolt megalopae

Adult blue crabs are often found in seagrass beds, as well as in other habitats in estuaries. They release chemical odors which can be detected by their prey (e.g. Duval et al. 1994). Megalopae could react to adults either as potential predators, or as markers of appropriate settlement habitat. Field settlement showed no response of settling megalopae to odors of adult blue crabs (Fig. 2c). This agrees with the result of Forward et al. (1994), who found that odors from adults had no effect on metamorphosis of megalopae. The fact that blue crabs are found in many habitats within estuaries also makes them unsuitable for indicating a specific favorable habitat. Thus, it is unlikely that the presence of adults indicates to megalopae that a settlement site is appropriate, as the presence of adult fiddler crabs Uca pugilator does for their megalopae (O'Connor 1991). It is also unlikely that megalopae have evolved an avoidance response to adult blue crabs due to predation, as laboratory feeding assays indicated that adults were not effective predators on megalopae (Fig. 6). It is possible that smaller juvenile blue crabs eat megalopae and that megalopae would react to them; this possibility is the subject of ongoing research in this laboratory. 
The hypothesis of selective settlement (see above) is also supported by the observed avoidance in the field of sand fiddler crabs Uca pugilator (Fig. 3a). These crabs occupy intertidal sandflats in the Newport River Estuary in densities of hundreds per $\mathrm{m}^{2}$, and can process over half of the intertidal sediment surface during exposure at low tide (Reinsel 1995). While $U$. pugilator do not seek out meio- and macrofauna as prey, they do eat them when they encounter them as they graze the sand particles for microalgae ( $K$. Reinsel pers. comm.). Clearly, any megalopa which settled on these sandflats would be likely to fall prey to fiddler crabs. Laboratory feeding assays showed that fiddler crabs ate megalopae encountered on a sand substrate (Fig. 6). Thus, predation pressure could underlie the observed avoidance behavior. In order for this avoidance to occur, it must be chemically mediated, because the time when megalopae would be settling (rising tide) is a time when fiddler crabs are in their burrows (Reinsel 1995) and not in contact with settling megalopae. Fiddler crabs do leave odors in sediment: Christy (1989) showed that sediment incubated with adult fiddler crabs accelerated metamorphosis of fiddler crab megalopae. The avoidance of chemicals released by $U$. pugilator is also shown in the chemotaxis assays, in which megalopae avoided the end of the chamber which had a higher concentration of odors from the fiddler crabs (Fig. 7).

In contrast to abundances in intertidal substrate, the low abundance of megalopae and first-stage crabs associated with unvegetated subtidal substrate (e.g. Orth \& van Montfrans 1987) cannot be linked to predator avoidance based on chemical cues. In field settlement experiments, megalopae showed no reaction to odors from the brown shrimp Penaeus aztecus which inhabits some of these areas (Fig. 3b, c). In addition, predation assays showed that $P$. aztecus did not eat megalopae (Fig. 6). Thus, these shrimp are both predicted and observed to have no effect on settlement of blue crab megalopae. As in the case of blue crabs, smaller individuals may be able to eat megalopae.

The use of salt marshes by settling blue crab megalopae was also examined. Settlement responses to odors from the dominant salt marsh vegetation Spartina alterniflora and 2 potential predators which reside in marshes, the mud fiddler crab Uca pugnax and the grass shrimp Palaemonetes pugio, were tested. It was hypothesized that odors from $S$. alterniflora would attract megalopae, since these odors have been shown to accelerate metamorphosis of blue crab megalopae in the laboratory (Forward et al. 1996) and to attract megalopae in other field experiments (Morgan et al. 1996). This was not the case, however. Both field settlement experiments (Fig. 4) and laboratory chemotaxis experiments (Fig 7) showed no response to odors from $S$. alterniflora. Settling megalopae avoided both $U$. pugnax and $P$. pugio (Fig. 4). These results, taken collectively, agree with those of Orth \& van Montfrans (1987) that salt marshes may be more important as juvenile habitat than as initial settlement sites.

Recently, it has been suggested that megalopae may be attracted to and settle in oyster reefs (Eggleston et al. 1997). Thus, odors associated with oyster beds were tested. Because biofilms and fouling organisms have been shown to act as settlement cues among some crustaceans (e.g. barnacles, Maki et al. 1988, Mary et al. 1993, Wieczorek et al. 1995), fouled oyster shells were tested. However, the fouled shells had no effect on settlement of blue crab megalopae (Fig. 6). It was then postulated that live oysters themselves might be emitting a cue to increase settlement in oyster beds. Unexpectedly, the oysters were a negative cue for settlement by blue crab megalopae (Fig. 5). Since oysters are unlikely to be predators on blue crab megalopae, it was hypothesized that megalopae may be avoiding organisms associated with oysters. One possible predator associated with oyster beds is the Atlantic mud crab Panopeus herbstii. Blue crab megalopae avoided collectors containing mud crabs more strongly than any other odor source tested (Fig 6) Mud crabs also were found to be the most effective predators on megalopae in laboratory predation assays, eating all megalopae presented to them (Fig. 7). Clearly, avoiding the presence of mud crabs would be an advantage for settling blue crabs.

Thus, no evidence was found to support a hypothesis of megalopae settling preferentially on or near oyster reefs. It is important to note, however, that these experiments examined only the effects of chemical odors from oyster reefs as settlement cues. It is possible that the physical structure and/or flow patterns offered by oyster reefs of fset the negative chemical cues for settlement. Megalopae in the present experiment were presented with identical physical environments; only the chemical environment differed. In Eggleston et al. (1997), there was a difference in the physical environments: oyster shell versus seagrass beds. The discrimination between sites in that case may have been dominated by reactions to physical cues, rather than chemical cues as examined in this study. Strong influences of physical factors have been shown in settlement site selection by postlarval and first instar spiny lobster (Herrnkind \& Butler 1986).

Taken collectively, the predation assays and field settlement experiments indicate that predation is a primary structuring force affecting megalopal settlement. Blue crab megalopae respond negatively to odors from megalopal predators, and show no reaction to odors from non-predators. This result indicates that avoidance of predation probably underlies the observed 
negative reactions. If a megalopa can detect the presence of a predator by its chemical odor and swim away from it, that individual is less likely to be eaten by that predator and thus more likely to survive, giving it a selective advantage over megalopae without this response.

If predator avoidance underlies the observed negative responses, why do blue crab megalopae avoid settling near oyster odors? The answer may be an avoidance of predators associated with mucus, since oysters, like other bivalves, produce mucus (e.g. Duval et al. 1994). Boudreau et al. (1993) related avoidance behavior of lobster postlarvae to fish odor, and one of the primary components of fish odor is mucus (e.g. Parrish \& Kroen 1988). Predator avoidance behavior (diel vertical migration) is induced in larvae of the mud crab Rhithropanopeus harrisii not only by mucus from predatory fishes such as killifish Fundulus heteroclitus but also by mucus from non-predators such ds mussels Geukensia demissa (Mckelvey 1997). Another example of mucus causing an 'inappropriate' predation avoidance response is found in Duval et al. (1994), in which the marsh periwintle Littoraria irrorata avoidcd mucus from $G$. demissa as strongly as they avoided mucus from their predators, tulip snails and horse conchs. Mucus from different taxa may be sufficiently similar to act as a general rather than a specific cue indicating the presence of a predator.

An important result seen throughout these experiments is the increased response of premolt megalopae to chemical odors. For example, in the case of seagrass, overall settlement was not different between treatment and control collectors, but premolt megalopae were attracted to collectors containing seagrass (Fig. 2). As discussed above, this response is unlikely to be due to induction of the progression toward metamorphosis. In contrast, when a negative settlement response was found, premolt megalopae were found on control collectors in higher proportion than on treatment collectors. Because the acceleration or deceleration of metamorphosis occurs on time scales of days (Forward et al. 1994, 1996), these results cannot be explained by the deceleration of metamorphosis of megalopae on collectors containing predators. The most logical explanation of this result is that premolt megalopae react more strongly to chemical cues than do intermolt megalopae.

In conclusion, blue crab megalopae use chemical cues to discriminate among potential settlement sites. Megalopae avoid sites with odors from predators which are able to eat them, but show no reaction to odors from animals unable to prey upon them. Megalopae in premolt have increased selective abilities over those in intermolt: they show positive selection for sites with seagrasses and enhanced negative selection for sites with predators
Acknowledgements. This material is based on research supported by the North Carolina Sea Grant (NA56FE0551) and the National Science Foundation (Grant no. OCE-9216629), and a Sigma Xi Grant-in-aid of Research (to J.W.). We thank Dimitri Blondel for his technical support and Gail Cannon for help with the collector figure

\section{LITERATURE CITED}

Aiken DE (1973) Proecdysis, setal development, and molt prediction in the American lobster (Homarus americanus). J Fish Res Bd Can 30:1337-1334

Boudreau B, Bourget E, Simard Y (1993) Behavioral responses of competent lobster postlarvae to odor plumes. Mar Biol 117:63-69

Burke RD (1984) Pheromonal control of metamorphosis in the Pacific sand dollar Dendraster excentncus. Science 225: $442-443$

Burke RD (1986) Pheromones and gregarious settlement of marine invertebrate larvae. Bull Mar Sci 39:323-332

Christy JH (1989) Rapid development of megalopae of the fiddier crab Uca pugilator reared over sediment: implications for models of larval recruitment. Mar Ecol Prog Ser 57: $259-265$

De Vries MC, Tankersley RA, Forward RB Jr, Kirby-Smith WW, Luettich RA Jr (1994) Abundance of estuarine crab idrvae is dssociated with tidai nydrologic variables. Mar Biol 118:403-413

Duval MA, Calzetta AM, Rittschof D (1994) Behavioral responses of Littoraria irrorata (SAY) to water-borne odors. J Chem Ecol 20:3321-3334

Eggleston DB, Etherington LL, Elis WE (1997) Organism response to habitat patchiness: species and habitatdependent recruitment of decapod crustaceans. J Exp Mar Biol Ecol (in press)

Forward RB $J_{r}$, De Vries MC, Rittschof D, Frankel DAZ, Bischoff JP, Fisher CM, Welch JM (1996) Effects of environmental cues on metamorphosis of the blue crab Callinectes saipidus. Mar Ecol Prog Ser 131:165-177

Forward RB Jr, Frankel DAZ, Rittschof D (1994) Molting of megalopae from the blue crab Callinectes sapidus: effects of offshore and estuarine cues. Mar Ecol Prog Ser 113: $55-59$

Forward RB Jr, Rittschof D (1994) Photoresponses of crab megalopae in offshore and estuarine waters: implications for transport. J Exp Mar Biol Ecol 182:183-192

Goodrich DM, van Montfrans J, Orth RJ (1989) Blue crab megalopal influx to Chesapeake Bay: evidence for a winddriven mechanism. Estuar Coast Shelf Scr 29:247-260

Herrnkind WF, Butler MJ (1986) Factors regulating postlarval settlement and juvenile microhabitat use by spiny lobsters Panulirus argus. Mar Ecol Prog Ser 34:23-30

Jensen GC (1989) Gregarlous settlement by megalopae of the porcelain crabs Petrolisthes cinctipes (Randall) and $P$. eriomerus Stimpson. J Exp Mar Biol Ecol 1.31:223-231

Lipcius RN, Olmı EJ III, van Montfrans J (1990) Planktonic availability, molt stage and settlement of blue crab postlarvat. Mar Ecol Prog Ser 58:235-242

Litlle KT, Epifanio CE (1991) Mechanism for the re-invasion of an estuary by two species of brachyuran megalopae. Mar Ecol Prog Ser 68:235-242

Luckenbach MW, Orth RJ (1992) Swimming velocities and behavior of blue crab (Callinectes sapidus Rathbun) megalopae in still and flowing water. Estuaries 15: $186-192$

Maki JS, Rittschof D, Costlow JD, Mitchell R (1988) Inhibition 
of attachment of larval barnacles Balanus-Amphitrite by bacterial surface films. Mar Biol 97:199-206

Mary A, Mary V, Rittschof D, Nagabhushanam R (1993) Bacterlal-barnacle interaction: potential of using juncellins and antibiotics to alter structure of bacterial communities. J Chem Ecol 19:2155-2167

McKelvey LM (1997) Predator chemical cues mediate zooplankton diel vertical migration. PhD thesis, Duke University, Beaufort, NC

Metcalf KS, van Montfrans J, Lupcius RN, Orth RJ (1995) Settlement indices for blue crab megalopae in the York River. temporal relationships and statistical efficiency. Bull Mar Sci 85:781-792

Morgan SG, Zimmer-Faust RK, Heck KL Jr, Coen LD (1996) Population regulation of blue crabs Callinectes sapidus in the northern Culf of Mexico: postlarval supply. Mar Ecol Prog Ser 133:73-88

O'Connor NJ (1991) Flexibility in timing of the metamorphic molt by fiddler crab megalopae Uca pugilator. Mar Ecol Prog Ser 68:243-247

Olmi EJ III (1994) Vertical migration of blue crab Callinectes sapidus megalopae: implications for transport in estuaries. Mar Ecol Prog Ser 113:39-54

Orth RJ, van Montfrans J (1987) Utilization of a seagrass meadow and tidal marsh creek by blue crabs Callinectes sapidus. I. Seasonal and annual variations in abundance with emphasis on post-settlement juveniles. Mar Ecol Prog Ser 41:283-294

Parrish JK, Kroen WK (1988) Sloughed mucus and dragreduction in a school of Atlantic silversides, Menidia

This article was submitted to the editor menidia. Mar Biol 97:165-169

Pawlik JR (1992) Induction of marine invertebrate larval settlement: evidence for chemical cues. In: Paul VJ (ed) Ecological roles of marine natural products. Cornell University Press, Ithaca, p 189-235

Provenzano AJ, McConaugha JR, Phillips $\mathrm{K}$, Johnson DF, Clark J (1983) Vertical distribution of first stage larvae of the blue crab, Callinectes sapidus, at the mouth of Chesapeake Bay. Estuar Coast Shelf Sci 16:489-500

Reinsel KA (1995) Intertidal grazers: Uca pugilator and the sandflat community. PhD thesis, Duke Unversity, Beautort, NC

Rittschof D, Forward RB Jr, Cannon G, Welch JM, McClary MM Jr, Holm ER, Clare AS, Conova S, McKelvey LM, Bryan P, Dover CLV (1997) Cues and context: larval responses to physical and chemical cues. Biofouling (in press)

Wieczorek SK, Clare AS, Todd CD (1995) Inhibitory and facilitatory effects of microbial films on settlement of Balanus amphitrite amphitrite larvae. Mar Ecol Prog Ser 119: $221-228$

Wolcott DL, De Vries MC (1994) Offshore megalopae of Callinectes sapidus: depth of collection, molt stage and response to estuarine cues. Mar Ecol Prog Ser 109: $157 \cdot 163$

Zar JH (1984) Biostatistical analysis, 2nd edn. Prentice-Hall, Englewood Cliffs, NJ

Zimmer-Faust RK, Tamburri MN (1994) Chemıcal identity and ecological implications of a waterborne, larval settlement cue. Limnol Oceanogr 39:1075-1087

Manuscnipt received: February 19, 1997 Revised version accepted: May 28, 1997 